\title{
Hepatic Steatosis in a Bullhead (Cottus gobio) Population from a High-Mountain Lake (Carnic Alps): Adaptation to an Extreme Ecosystem?
}

\author{
Paolo Pastorino ${ }^{1,2, *(\mathbb{D}, \text { Marino Prearo }}{ }^{2}$, Elisabetta Pizzul ${ }^{1}$, Marco Bertoli ${ }^{1}$, \\ Danila Raffaella Francese ${ }^{2}$, Vasco Menconi ${ }^{2}$, Davide Mugetti ${ }^{2}$, Elena Bozzetta ${ }^{2}$ \\ and Katia Varello 2 (D) \\ 1 Department of Life Sciences, University of Trieste, via Giorgieri 10, 34127 Trieste, Italy; pizzul@units.it (E.P.); \\ marco.ber3@gmail.com (M.B.) \\ 2 Istituto Zooprofilattico Sperimentale del Piemonte, Liguria e Valle d'Aosta, Via Bologna 148, \\ 10154 Torino, Italy; marino.prearo@izsto.it (M.P.); danilaraffaella.francese@izsto.it (D.R.F.); \\ vasco.menconi@izsto.it (V.M.); davide.mugetti@izsto.it (D.M.); elena.bozzetta@izsto.it (E.B.); \\ katia.varello@izsto.it (K.V.) \\ * Correspondence: paolo.pastorino@izsto.it; Tel.: +39-011-268-6295
}

Received: 4 November 2019; Accepted: 4 December 2019; Published: 5 December 2019

\begin{abstract}
The aim of this study was to describe liver alterations observed in a bullhead (Cottus gobio) population from a high-mountain lake (Dimon Lake; $1857 \mathrm{~m}$ a.s.l.) located in Carnic Alps (Northeast Italy). Two fish sampling campaigns (summer and autumn) were performed in 2017 to explore the possible causes of this phenomenon. In addition, to investigate the typical liver features of C. gobio, control specimens were captured from Degano Creek in the same seasons. Total length, weight, and liver weight were recorded in fish from both sampling sites. In addition, Fulton's condition factor $(\mathrm{K})$ and hepatosomatic index (HSI) were calculated. Stomach contents were also analyzed. Liver from each specimen was sampled, and histological examination was carried out. Liver steatosis (L) (nuclear displacement and cytoplasm vacuolization) were histologically evaluated by assigning a semiquantitative severity score. A significant difference in $\mathrm{L}$ was found between Dimon Lake and Degano Creek in both summer (Mann-Whitney test; $p=0.0001$ ) and autumn (Mann-Whitney test; $p<0.0001)$. Regarding HSI, a significant difference was also recorded between Dimon Lake and Degano Creek in summer (Mann-Whitney test; $p<0.0001$ ) and also in autumn (Mann-Whitney test; $p<0.0001$ ), but no seasonal change in $\mathrm{K}$ values was recorded between the two sites in both summer (Mann-Whitney test; $p=0.8589$ ) and autumn (Mann-Whitney test; $p=0.6415)$. A significant positive correlation between HSI and L was found ( $\rho$ S 0.573). The causes of this abnormality might be related to adaptation by the fish to the high-altitude environment, accumulating lipids in the liver to tackle the adverse season, which lasts for 6 months of the year. Nonetheless, our study does not preclude steatosis induced by a nearly exclusive chironomids diet in bullhead from Dimon Lake.
\end{abstract}

Keywords: adaptation; alpine lakes; Cottus gobio; hepatic steatosis

\section{Introduction}

Alpine lakes are extreme ecosystems with harsh climatic conditions. Though located in remote areas, they may be affected by local anthropogenic impacts, such as fish introduction. Most alpine lakes were, in fact, originally fishless, isolated ecosystems. Owing to the relatively small number of native species, the lakes have low resilience to disturbances and can be especially sensitive to the introduction of alien fish for recreational fishing. During the greater part of the year, snow and ice cover prevents sunlight from penetrating the lake water column [1]. Without the penetration of 
light, photosynthesis is not possible, and the lake waters remain in a long period of darkness [2], becoming a heterotrophic system isolated from the surrounding area. In early summer, when the snow melts, the lakes quickly shift from extremely low to extremely high solar irradiance correlated with altitude. Low oxygen availability and low temperatures make life at such altitudes challenging, though many species have adapted successfully via physiological changes. Unlike short-term acclimatization (immediate physiological response to a changing environment), high-altitude adaptation means irreversible, evolved physiological responses to high-altitude environments, associated with behavioral and genetic changes.

Published data on fish adaptation to high-altitude environments are scarce. For example, some studies have focused on metabolic rate, as reported in highland westslope cutthroat trout (Oncorhynchus clarkii) as compared with introduced lowland rainbow trout (Oncorhynchus mykiss) in the Oldman River basin (Canada): Fish at high altitudes have a lower metabolic rate [3]. Kang and co-workers [4] investigated the genetic mechanism of high-altitude adaptation in Creteuchiloglanis macropterus (Siluriformes) and found that many genes were involved in energy metabolism and hypoxia, which might be an important resource for studying adaptations to a high-altitude environment. Li and co-workers [5] characterized the mitochondrial genomes of two species ("morphologically primitive" clade and "morphologically specialized" clade) of schizothoracine fishes. They reported evidence for positive selection acting on the protein-encoding genes in the mitochondrial genomes of the "morphologically specialized" clade, implying a possible genetic basis for high-altitude adaptation in this derived lineage of cypriniform fish.

Other studies on macrobenthic invertebrates in streams have showed a decrease in species richness with increasing altitude due to lower oxygen saturation rather than low temperature [6]. These factors may reduce productivity in high-altitude ecosystems, meaning there will be less energy available for consumption, growth, and activity, which provides a survival advantage to fish with lower metabolic demands. During 2017, two fish sampling campaigns were conducted in a high-mountain lake (Dimon Lake) located in the Carnic Alps (northeast Italy). Liver examination revealed alterations in specimens of the bullhead (Cottus gobio). The aim of this study was to describe the liver alterations observed in C. gobio and discuss the possible causes of this abnormality.

\section{Materials and Methods}

\subsection{Study Sites}

The main study site was Dimon Lake $\left(46^{\circ} 34^{\prime} 05.4^{\prime \prime} \mathrm{N} ; 13^{\circ} 03^{\prime} 45.8^{\prime \prime} \mathrm{E}\right)$, a high-mountain lake located in the Carnic Alps (municipality of Ligosullo, Udine Province, Friuli Venezia-Giulia Region, northeast Italy) at $1857 \mathrm{~m}$ a.s.l. The Carnic Alps are among the most remote areas in Italy. Anthropic impacts are very limited, except for pasturing activity. Dimon Lake is a typical glacial-origin lake, classified as a Site of Community Interest and Special Areas of Conservation (SCI/SAC-IT3320002 "Monti Dimon e Paularo"). Originally a fishless lake, fish were introduced for recreational fishing in the past [7]. The lake lies on sandstone and volcanic rocks; it measures $376 \mathrm{~m}$ in perimeter, 0.6 ha in surface area, and has a maximum depth of $4.27 \mathrm{~m}$. For the purposes of comparison in this study, C. gobio individuals were captured in Degano Creek ( $\left.46^{\circ} 26^{\prime} 21.9^{\prime \prime} \mathrm{N} ; 12^{\circ} 52^{\prime} 43.6^{\prime \prime} \mathrm{E}\right)$, a sub-alpine watercourse near the municipality of Raveo (520 m a.s.l.), about $40 \mathrm{~km}$ from Dimon Lake, with scarce human impacts (Figure 1). The comparison of lake vs. stream populations was dictated by the absence of $C$. gobio in other high-altitude lakes in northeast Italy. 


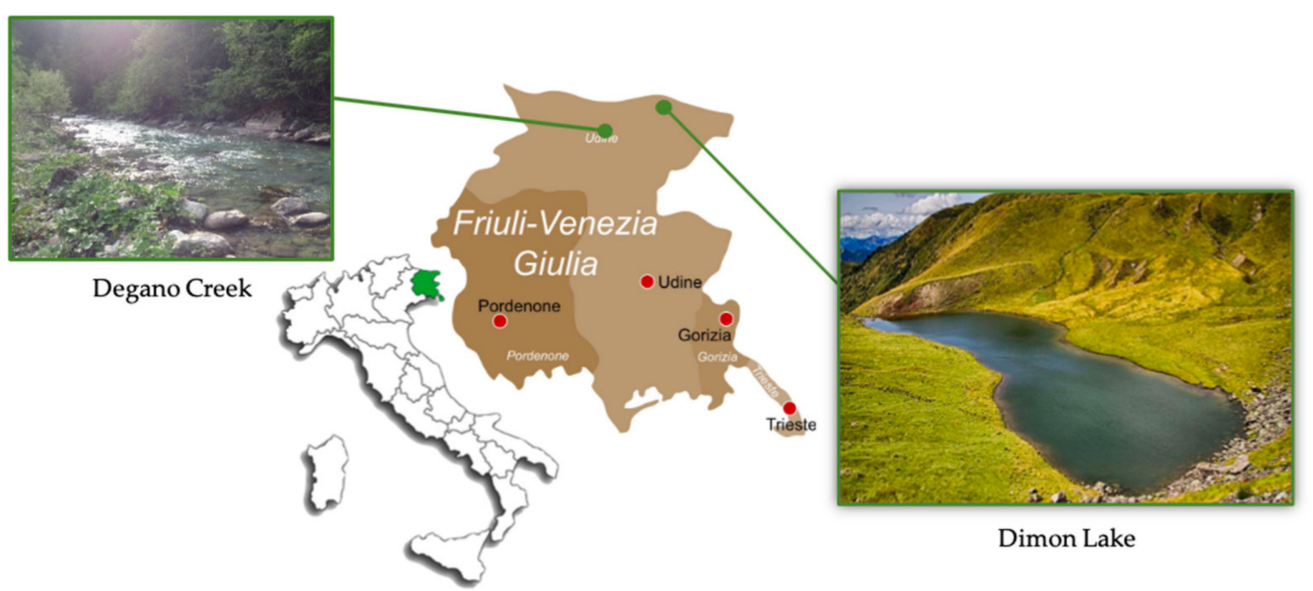

Figure 1. Location of fish sampling sites in Friuli Venezia-Giulia, Italy. Degano Creek (pictured on the left) and Dimon Lake (pictured on the right).

\subsection{Fish Sampling}

In 2017, two fish sampling campaigns (July and October) were performed. These two months were chosen because of accessibility, which is usually limited by snowfall from early November to June. Fish were sampled using an electrofishing boat in both the littoral and the deep zones (maximum depth $4.27 \mathrm{~m})$. The fish were identified and measured for length $(\mathrm{TL} ; \mathrm{cm})$ and weight $(\mathrm{W} ; \mathrm{g})$. Fulton's condition factor $(\mathrm{K})$ was also calculated for each specimen. The $\mathrm{K}$ factor was derived from the following formula [8]:

$$
\mathrm{K}=\left(\mathrm{W} / \mathrm{TL}^{3}\right) \times 100,
$$

where $\mathrm{W}$ is the weight $(\mathrm{g})$ and TL is the total length of the fish (cm). A total of 35 fish (15 in the summer and 20 in the autumn campaign) were sampled, euthanized with an overdose of tricaine methanesulfonate MS-222 (50 $\left.\mathrm{mg} \mathrm{kg}^{-1}\right)$, and then necropsied. The liver from each specimen was weighted to calculate the hepatosomatic index (HSI) using the formula [9]:

$$
\text { HSI }(\%)=(L W / F W) \times 100,
$$

where LW is the liver weight (g) and FW is the whole weight of the fish (g). Liver was sampled for histological evaluation. Only larger fish were selected in order to have enough material for all histological analyses (see Section 2.4). Moreover, as control fish, we also performed two sampling campaigns in the same periods (July and October) using electrofishing in Degano Creek. Only 10 individuals both for summer and autumn were captured to avoid putting pressure on the wild native population. TL, W, and LW were determined and HSI and K were calculated. Fish sampling campaigns were performed by permission of Ente Tutela Patrimonio Ittico del Friuli Venezia-Giulia (authorization n. 11/DIR/17/01/2017).

\subsection{Analysis of Stomach Contents}

In both sampling campaigns the stomach contents of the fish from Dimon Lake were analyzed to obtain more detailed information about their diet. The stomachs were preserved in alcohol $70 \%$ and the content was identified by optical microscope (Olympus BX40, Olympus, Tokyo, Japan) and stereomicroscope (Zeiss Stemis V8, Zeiss, Shangkeheng, Germany). An attempt was made to identify the ingested prey to the lowest recognizable taxa, but accurate identification was often not possible due to digestion of the prey. Stomach content analysis was also performed on the fish from Degano Creek. In order to describe the diet, the prey frequency of occurrence ( $\mathrm{Fi}$ ) [10] was calculated for both seasons. 


\subsection{Histological Evaluation}

A total of 35 liver samples were partly fixed in $10 \%$ neutral buffered formalin and partly frozen. The fixed tissues were dehydrated in a gradual series of alcohols and embedded in paraffin. The paraffin blocks were cut into $4 \pm 2 \mathrm{~mm}$ sections and stained with hematoxylin and eosin (HE) for microscopic evaluation. Histological changes (nuclear displacement and cytoplasm vacuolization) to define liver steatosis were evaluated and a semiquantitative severity score was assigned: 0 -not observed; 1-mild; 2-moderate; 3-severe [11]. Histochemical stains, Periodic-acid Schiff (PAS) to detect mucopolysaccharides and Sudan III to detect lipids, were also performed [12]. Slides were evaluated microscopically at increasing magnification $(10 \times, 20 \times, 40 \times)$ on a Zeiss Axio Scope.A1 microscope. Samples were considered positive for the presence of red-purple glycogen or orange lipidic deposits in hepatocyte cytoplasm for PAS and Sudan III stain, respectively.

\subsection{Statistical Analysis}

The Wilcoxon test was performed to compare (a) the liver steatosis score $(\mathrm{L})$, (b) the hepatosomatic index (HSI), and (c) the K values between seasons in Dimon Lake and in Degano Creek. Mann-Whitney $\mathrm{U}$ tests were used for pairwise comparison of L, HSI, and K values of C. gobio in Dimon Lake vs. Degano Creek in both summer and autumn. Spearman's rank correlation coefficient $(\rho S)$ was used to test correlations between L, W, HIS, and K. Differences were considered significant with a $p$ value $<0.05$. All statistical analyses were performed using GraphPad Prism version 8.0.1 (GraphPad Software, San Diego, CA, USA).

\section{Results}

\subsection{Fish Sampling and Anatomopathological Features}

Values of TL, W, K, LW, and HIS for C. gobio captured in Dimon Lake and Degano Creek are reported in Tables 1 and 2, respectively.

Regarding Dimon Lake, the average TL for $C$. gobio captured during the summer campaign was $13.88 \pm 1.12 \mathrm{~cm}$, with an average $\mathrm{W}$ of $31.20 \pm 7.54 \mathrm{~g}$. The average TL of individuals captured during autumn was $13.25 \pm 1.37$ with an average $W$ of $26.70 \pm 6.89 \mathrm{~g}$. $\mathrm{K}$ values ranged between $1.15 \pm 0.12$ in summer and $1.14 \pm 0.15$ in autumn. LW ranged between $0.85 \pm 0.14$ in summer and $0.82 \pm 0.24$ in autumn. HSI ranged between $2.80 \pm 0.38$ in summer and $3.08 \pm 0.39$ in autumn (Table 3). At necropsy, the livers appeared variably pale to yellowish in color and friable in consistency; no visible lesions in the other visceral organs were observed (Figure 2).

In Degano Creek, the average TL of individuals captured during summer was $14.24 \pm 0.86 \mathrm{~cm}$ with an average $\mathrm{W}$ of $33.60 \pm 6.15 \mathrm{~g}$. Instead, during autumn, individuals showed a TL of $12.36 \pm 1.76 \mathrm{~cm}$ with a $\mathrm{W}$ of $23.10 \pm 9.04 \mathrm{~g}$. K values ranged between $1.16 \pm 0.14$ in summer and $1.17 \pm 0.14$ in autumn. LW ranged between $0.54 \pm 0.12$ in summer and $0.36 \pm 0.14$ in autumn. HIS ranged between $1.60 \pm 0.15$ in summer and $1.60 \pm 0.10$ in autumn (Table 3). No lesions in organs were observed, liver included (Figure 3).

Statistical analysis showed no seasonal differences in the liver steatosis score in Dimon Lake (Wilcoxon test; $p=0.6719$ ), but a significant difference was found between Dimon Lake and Degano Creek in both summer (Mann-Whitney test; $p=0.0001$ ) and autumn (Mann-Whitney test; $p<0.0001$ ) (Table 3). Regarding HSI, no seasonal differences were observed in Dimon Lake (Wilcoxon test; $p=0.1173)$, but a significant difference were recorded between Dimon Lake and Degano Creek in summer (Mann-Whitney test; $p<0.0001$ ) and also in autumn (Mann-Whitney test; $p<0.0001$ ) (Table 3). No seasonal change in $\mathrm{K}$ values was recorded in Dimon Lake (Wilcoxon test; $p=0.5696$ ), not even between Dimon Lake and Degano Creek in both summer (Mann-Whitney test; $p=0.8589$ ) and autumn (Mann-Whitney test; $p=0.6415$ ). A significant positive correlation between HIS and L was found ( $\rho S$ 0.573). 
Table 1. Total length (TL), weight (W), liver weight (LW), hepatosomatic index (HSI), Fulton's condition factor $(\mathrm{K})$, and liver steatosis score $(\mathrm{L})$ of Cottus gobio $(\mathrm{N})$ captured during summer and autumn in Dimon Lake.

\begin{tabular}{cccccccc}
\hline Season & $\mathbf{N}$ & TL $(\mathbf{c m})$ & $\mathbf{W}(\mathbf{g})$ & $\mathbf{L W}(\mathbf{g})$ & HSI & $\mathbf{K}$ & $\mathbf{L}$ \\
\hline \multirow{5}{*}{ Summer } & 1 & 14.0 & 29 & 0.803 & 2.77 & 1.06 & 2 \\
& 2 & 15.3 & 38 & 0.927 & 2.44 & 1.06 & 1 \\
& 3 & 15.3 & 37 & 0.925 & 2.50 & 1.03 & 2 \\
& 4 & 14.9 & 29 & 0.913 & 3.15 & 0.88 & 2 \\
& 5 & 13.1 & 27 & 0.867 & 3.21 & 1.20 & 3 \\
& 6 & 15.4 & 46 & 1.090 & 2.37 & 1.26 & 0 \\
& 8 & 14.5 & 41 & 0.914 & 2.23 & 1.34 & 2 \\
& 9 & 13.5 & 32 & 0.877 & 2.74 & 1.30 & 3 \\
& 10 & 15.0 & 39 & 0.874 & 3.36 & 1.13 & 3 \\
& 11 & 13.4 & 31 & 0.965 & 2.32 & 1.16 & 2 \\
& 12 & 13.5 & 27 & 0.877 & 3.11 & 1.29 & 3 \\
& 13 & 12.2 & 20 & 0.594 & 2.97 & 1.10 & 2 \\
& 14 & 12.5 & 25 & 0.767 & 3.07 & 1.28 & 3 \\
& 15 & 12.4 & 21 & 0.540 & 2.57 & 1.10 & 1 \\
\hline \multirow{5}{*}{ Autumn } & 16 & 14.3 & 37 & 1.424 & 3.85 & 1.27 & 3 \\
& 17 & 12.3 & 19 & 0.507 & 2.67 & 1.02 & 0 \\
& 18 & 14.5 & 37 & 0.884 & 2.39 & 1.21 & 3 \\
& 19 & 12.4 & 26 & 0.946 & 3.64 & 1.36 & 2 \\
& 20 & 12.0 & 17 & 0.530 & 3.12 & 0.98 & 3 \\
& 21 & 14.5 & 31 & 0.973 & 3.14 & 1.02 & 3 \\
& 22 & 15.5 & 33 & 0.861 & 2.61 & 0.89 & 2 \\
& 23 & 15.0 & 32 & 0.896 & 2.80 & 0.95 & 1 \\
& 26 & 15.5 & 39 & 1.197 & 3.07 & 1.05 & 3 \\
& 27 & 13.5 & 23 & 0.655 & 2.85 & 0.93 & 3 \\
& 28 & 13.5 & 34 & 1.231 & 3.62 & 1.12 & 3 \\
& 29 & 11.0 & 26 & 0.738 & 2.84 & 1.18 & 2 \\
& 30 & 12.5 & 24 & 0.578 & 2.89 & 1.50 & 2 \\
& 31 & 13.5 & 27 & 0.896 & 3.32 & 1.10 & 3 \\
& 32 & 11.8 & 19 & 0.606 & 3.19 & 1.16 & 3 \\
& 33 & 12.0 & 20 & 0.674 & 3.37 & 1.16 & 3 \\
& 34 & 11.7 & 19 & 0.589 & 3.10 & 1.19 & 3 \\
& 35 & 12.0 & 23 & 0.718 & 3.12 & 1.33 & 3 \\
\hline
\end{tabular}

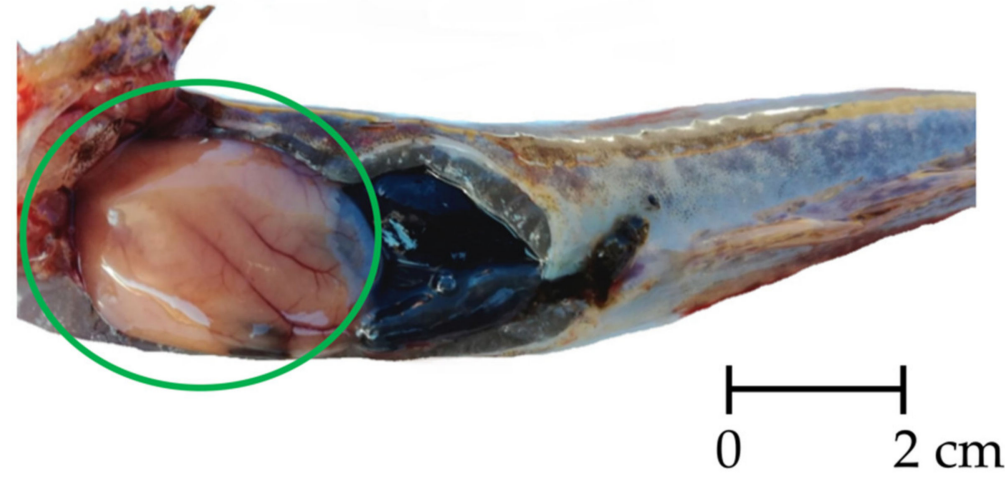

Figure 2. Macroscopical aspect of liver from Cottus gobio captured in Dimon Lake during autumn 2017. It appears pale to yellowish in color and friable in consistence (green circle). 


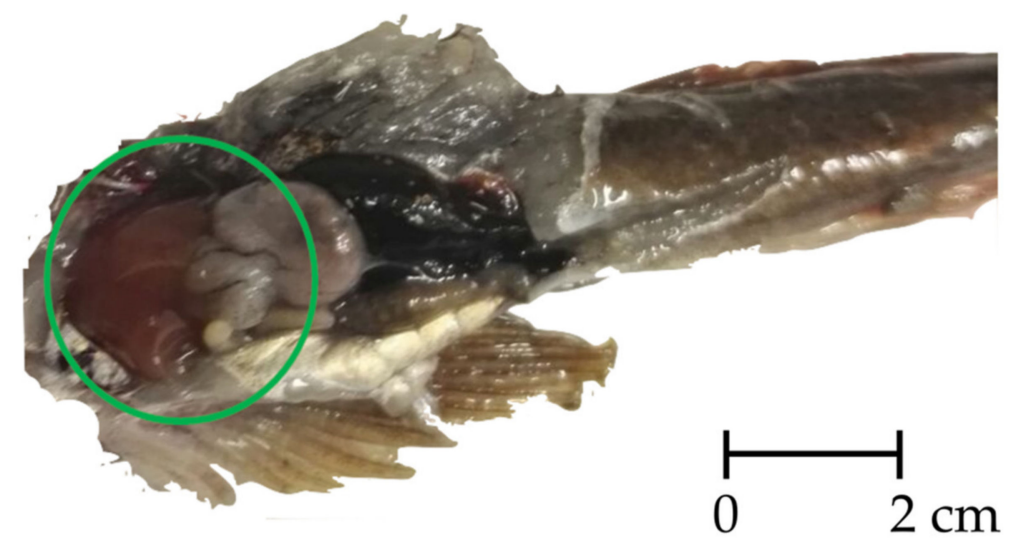

Figure 3. Macroscopical aspect of normal liver (green circle) of Cottus gobio captured in Degano Creek during autumn 2017.

Table 2. Total length (TL), weight (W), liver weight (LW), hepatosomatic index (HSI), Fulton's condition factor $(\mathrm{K})$, and liver steatosis score $(\mathrm{L})$ in individuals of Cottus gobio $(\mathrm{N})$ captured during summer and autumn in Degano Creek.

\begin{tabular}{cccccccc}
\hline Season & $\mathbf{N}$ & TL $(\mathbf{c m})$ & $\mathbf{W} \mathbf{( g )}$ & $\mathbf{L W} \mathbf{( g )}$ & $\mathbf{H S I}$ & $\mathbf{K}$ & $\mathbf{L}$ \\
\hline & 1 & 13.5 & 27 & 0.407 & 1.509 & 1.10 & 0 \\
& 2 & 14.2 & 40 & 0.768 & 1.920 & 1.40 & 1 \\
& 3 & 15.4 & 38 & 0.566 & 1.490 & 1.04 & 0 \\
Summer & 4 & 14.9 & 31 & 0.478 & 1.543 & 0.94 & 0 \\
(July) & 5 & 15.1 & 37 & 0.661 & 1.789 & 1.07 & 1 \\
& 7 & 13.1 & 25 & 0.390 & 1.560 & 1.11 & 1 \\
& 7 & 14.5 & 41 & 0.598 & 1.458 & 1.34 & 0 \\
& 8 & 13.5 & 32 & 0.530 & 1.657 & 1.30 & 0 \\
& 10 & 13.2 & 26 & 0.429 & 1.652 & 1.13 & 1 \\
& 15.0 & 39 & 0.575 & 1.475 & 1.16 & 0 \\
\hline \multirow{5}{*}{ (Outumn } & 11 & 11.2 & 16 & 0.282 & 1.766 & 1.14 & 0 \\
& 12 & 13.2 & 26 & 0.402 & 1.547 & 1.13 & 0 \\
& 13 & 10.7 & 15 & 0.244 & 1.631 & 1.18 & 0 \\
& 14 & 14.1 & 38 & 0.622 & 1.639 & 1.36 & 1 \\
& 16 & 13.0 & 24 & 0.416 & 1.735 & 1.09 & 0 \\
& 17 & 10.6 & 14 & 0.216 & 1.542 & 1.14 & 0 \\
& 18 & 14.4 & 16 & 0.253 & 1.584 & 1.29 & 1 \\
& 19 & 10.7 & 17 & 0.462 & 1.651 & 0.93 & 0 \\
& 20 & 15.0 & 37 & 0.531 & 1.479 & 1.39 & 1 \\
& & & & & & & \\
\hline
\end{tabular}

Table 3. Mean and standard deviation of total length (TL), weight (W), liver weight (LW), hepatosomatic index (HSI), Fulton's condition factor (K) and median values of liver steatosis score (L) in individuals of Cottus gobio $(\mathrm{N})$ captured during summer and autumn in Dimon Lake and Degano Creek. Lowercase letters indicate statistically significant differences between sites in summer (a) and autumn (b) $(p<$ 0.05).

\begin{tabular}{ccccccccc}
\hline Site & Season & $\mathbf{N}$ & TL $\mathbf{( c m})$ & $\mathbf{W}(\mathbf{g})$ & $\mathbf{K}$ & $\mathbf{L W}(\mathbf{g})$ & HSI & L \\
\hline \multirow{2}{*}{ Dimon } & Summer & 15 & $13.88 \pm 1.12$ & $31.20 \pm 7.54$ & $1.15 \pm 0.12$ & $0.85 \pm 0.14$ & $2.80 \pm 0.38^{\mathrm{a}}$ & $2^{\mathrm{a}}$ \\
& Autumn & 20 & $13.25 \pm 1.37$ & $26.70 \pm 6.89$ & $1.14 \pm 0.15$ & $0.82 \pm 0.24$ & $3.08 \pm 0.39^{\mathrm{b}}$ & $3^{\mathrm{b}}$ \\
\hline \multirow{2}{*}{ Degano } & Summer & 10 & $14.24 \pm 0.86$ & $33.6 \pm 6.15$ & $1.16 \pm 0.14$ & $0.54 \pm 0.12$ & $1.60 \pm 0.15^{\mathrm{a}}$ & $0^{\mathrm{a}}$ \\
& Autumn & 10 & $12.36 \pm 1.76$ & $23.1 \pm 9.04$ & $1.17 \pm 0.14$ & $0.36 \pm 0.14$ & $1.60 \pm 0.10^{\mathrm{b}}$ & $0^{\mathrm{b}}$ \\
\hline
\end{tabular}




\subsection{Stomach Contents Analysis}

The analysis of the stomach contents showed that C. gobio from Dimon Lake fed chiefly on Chironomidae larvae in both summer (96.18\%) and autumn (98.30\%). Other taxa were present in extremely low proportions (Chironomidae pupae: $3.18 \%$ in summer and $0.79 \%$ in autumn; Tricoptera: $0.64 \%$ in summer and $0.39 \%$ in autumn; Tricoptera Limnephilidae: $0 \%$ in summer and $0.52 \%$ in autumn). Stomach content analysis of the Degano Creek fish revealed Tricoptera $(42.63 \%$ in summer; $34.03 \%$ in autumn), Ephemeroptera (7.5\% in summer; $5.8 \%$ in autumn), and Plecoptera (4.1\% in summer and $2.5 \%$ in autumn).

\subsection{Histological Analysis}

Histology of the liver samples of C. gobio from Dimon Lake showed a range of cytoplasm vacuolization of hepatocytes from mild (score 1) to severe (score 3 ) in 33 specimens, with multifocal to diffuse localization (Figure 4). Only two specimens showed no hepatic lesions (score 0). Nuclear displacement and cytoplasm vacuolization are depicted in Figure 5. Table 1 presents the liver steatosis score (L) for each specimen examined. Table 3 presents median values of L for both seasons.

Sudan III was positive in all the samples with a high vacuolization score (2-3) (Figure 6a). PAS stain positivity was inversely proportional to the histological score (Figure 6b). Fish with grade 3 showed only rare residual glycogen deposits in hepatocytes.

Finally, individuals used as the control and sampled from Degano Creek showed no hepatocyte vacuolization (score 0; Figure 4a) in both seasons, except a few cases with a score of 1 . Median values of $\mathrm{L}$ are also reported in Table 3.

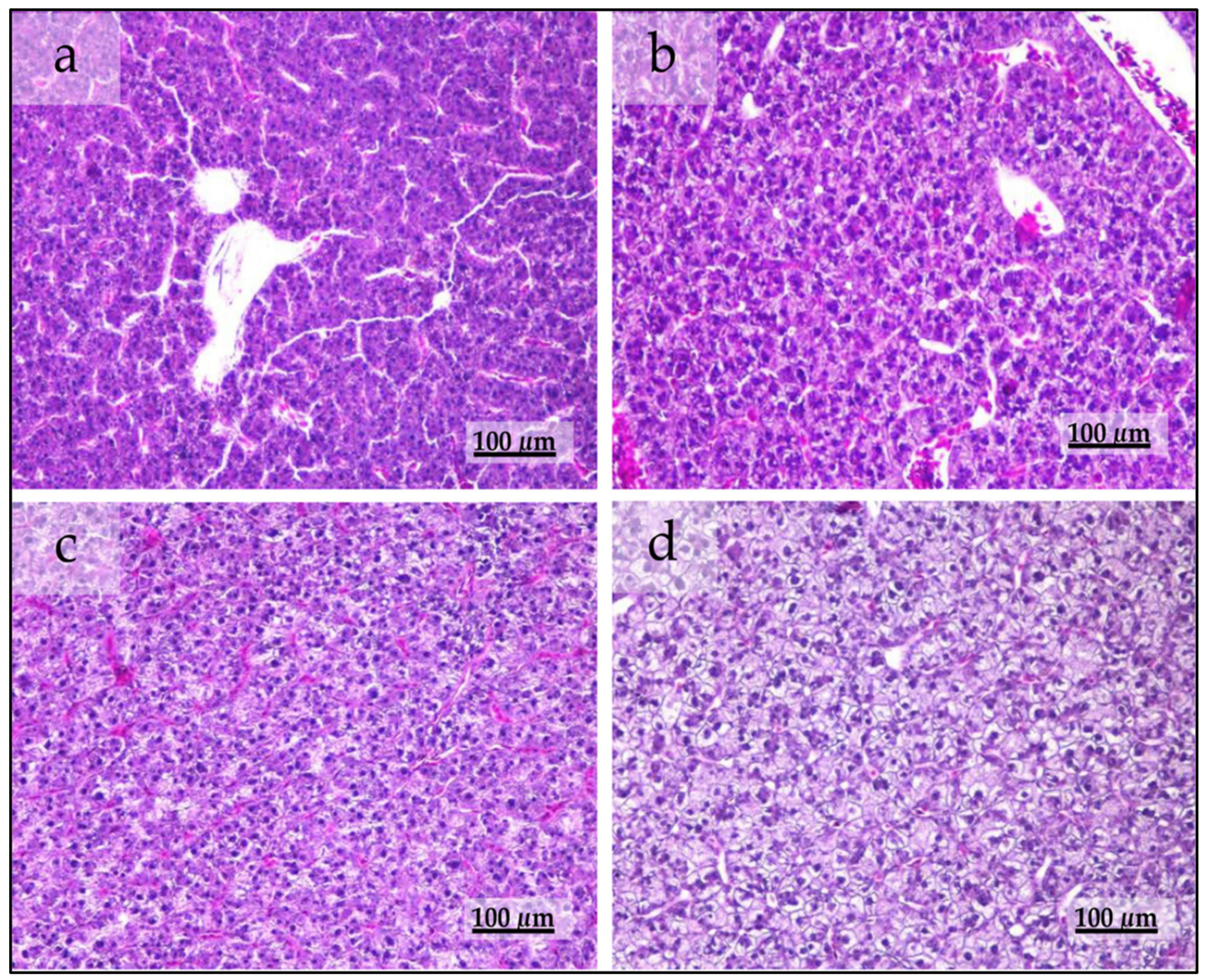

Figure 4. Liver sections of Cottus gobio (HE): (a) no vacuolization observed in hepatocytes (control); (b) mild vacuolization; (c) moderate vacuolization; (d) severe, diffuse vacuolization. 


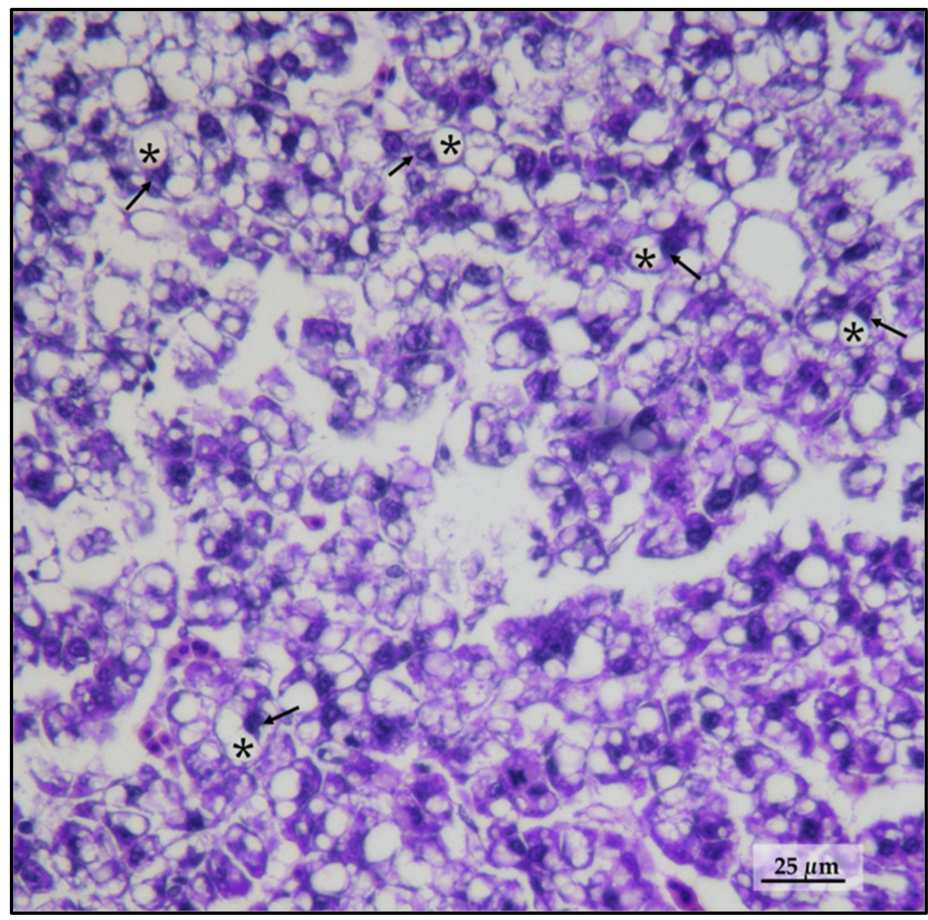

Figure 5. Liver section of Cottus gobio (HE) from Dimon Lake: detail of Figure 4d with nuclear displacement (black arrow) and cytoplasm vacuolization (asterisk).

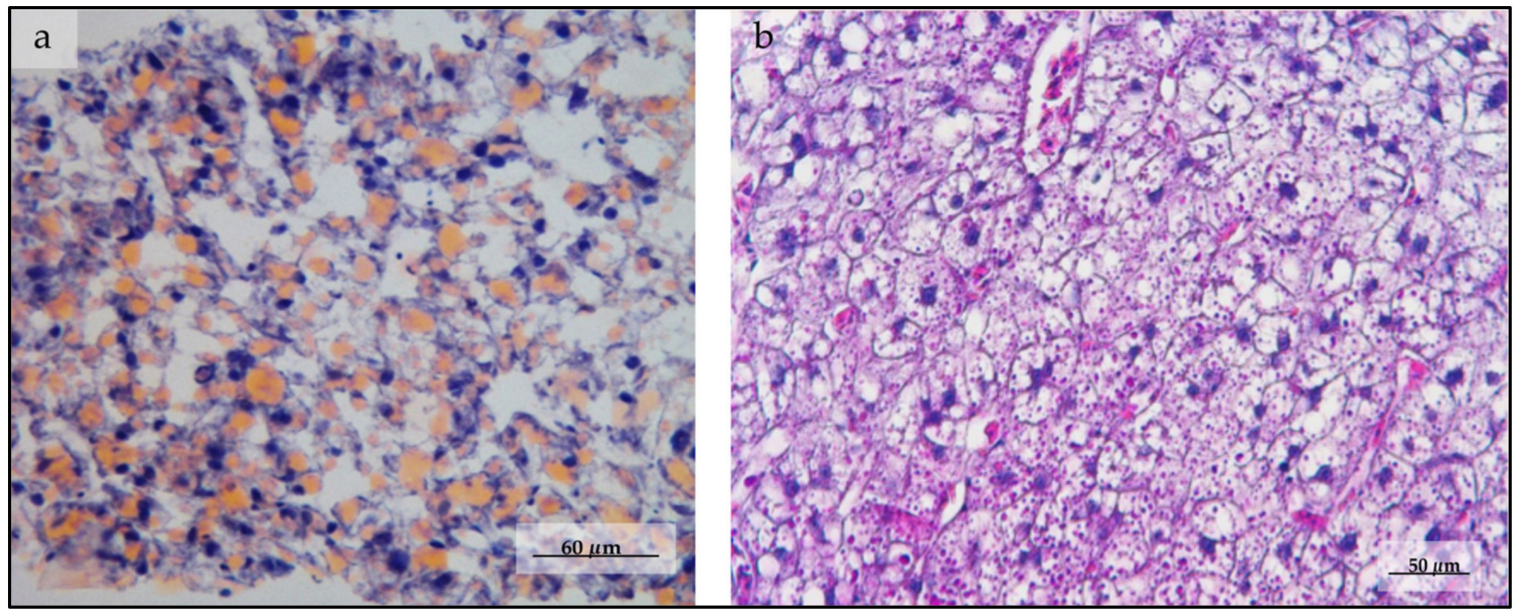

Figure 6. Liver sections of Cottus gobio from Dimon Lake. (a) Sudan III stain; orange lipidic deposits in hepatocyte cytoplasm of a subject with a high vacuolization score (3); (b) Periodic-acid Schiff (PAS) stain: red-purple residual glycogen deposits in hepatocyte cytoplasm of bullhead classified as grade 3.

\section{Discussion}

High-altitude ecosystems are rare and important habitats that host endemic and endangered species characterized by specific adaptations to extreme conditions. These ecosystems are often subject to direct anthropic pressure, such as the introduction of alien species. For example, fish species introduced for recreational fishing in originally fishless alpine lakes in Italy [13] have become a serious threat to aquatic biodiversity, especially for amphibian communities. Species (predators, such as salmonids, but also forage fish) reared in aquaculture facilities were transported by fishermen or fishing associations, placed in these environments, and forced to live in oligotrophic waters with scarce prey [14]. Bullhead (Cottus gobio) naturally inhabits stony-bottom, oxygen-rich, cool-water streams and rivers. The altitude ranges from high-altitude streams to lowland rivers. Cottus gobio is a 
retiring fish [15]. This relates to its high vulnerability to predation; for this reason, cover and shade are extremely important habitat features for bullhead. Generally, the bullhead diet is based on benthic invertebrates and its feeding activity is concentrated around dawn and dusk because it is susceptible to predators during the day. While autochthonous to the Padano-Veneto district (Friuli-Venezia Giulia included) [16], the species was introduced accidentally with brook trout (Salvelinus fontinalis) to Dimon Lake in the 1980s [17]. S. fontinalis is presumably no longer present in the lake since we caught none.

Our study started with the aim of exploring the fish community of the lake. After discovering bullhead specimens with pronounced steatosis, we decided to investigate this abnormal condition and pose a hypothesis for its cause. Stomach contents analysis was performed to understand nutritional requirements, trophic and energy dynamics, food webs, food chains, material, and energy transfers between and within ecosystems [18]. This is an important part of studying feeding habits and, in general terms, a necessary step in research into the more complex questions of freshwater fish ecology. We analyzed the stomach contents of C. gobio sampled during two seasons both in Dimon Lake and Degano Creek to determine whether there were differences in diet across the two seasons [18]. Stomach content analysis showed that $C$. gobio from Dimon Lake feed mostly on Chironomidae larvae. This could be justified by the relative, great abundance, and almost exclusive presence of Chironomidae larvae in the lake [19], and it could also be explained by the feed ecology of this species, since this taxon is most easy to prey than other aquatic macroinvertebrates. In fact, C. gobio is a stationary benthic feeder, which shows a well-developed homing instinct [20]. Indeed, Hirudinea and Oligochaeta taxa are also present in this lake [19], but more endobenthic than Chironomidae, thus more difficult to hunt, justifying the bullhead preference for Chironomidae. Generally, C. gobio prey on a wide range of insect larvae as Plecoptera, Trichoptera, Ephemeroptera, and Diptera [21-24], as recorded in Degano Creek. Nevertheless, bullhead was found to be predominantly food generalists, with an ability to shift their feeding strategy towards specialization when exposed to environmental disturbances [25]. Comparison of the histological evaluations on fish from the two different sites (lake vs. stream) showed that only C. gobio from Dimon Lake was affected by medium-severe (score 2-3) liver steatosis. Lipid accumulation in the hepatocytes in this species or in fish living in other alpine lakes has never been reported in the literature to date. Our study is the first report of this phenomenon. Two hypotheses for the causes of these histological alterations can be offered. The first posits for adaptation of the fish to the winter season, which in this type of environment lasts for 6 months of the year. Our results clearly reveal that HSI values were significantly lower in Degano Creek compared to Dimon Lake in both seasons. Furthermore, a slight increase in the hepatosomatic index was recorded in autumn compared to summer in Dimon Lake. In this situation, it can be assumed that the bullhead from Dimon Lake accumulates lipids in the liver and then use them as fuel for energy in the adverse season (winter).

Adaptive processes are often based on biochemical and physiological adaptations. Lipids play a key role in biochemical adaptation in animals, especially in aquatic organisms, and they are of pivotal importance for long-term energy storage. Adaptations provide an effective response to stressors (e.g., changes in water temperature or oxygen). In some cases, fish may be able to adapt by changing their behavior, but more often it is through physiological adaptations, especially at the cell membrane level. Temperature, for instance, can be considered a stressor that acts to establish a new balance between the environment and the biochemical properties of cell membranes. Fish respond to environmental temperatures by activating a suite of compensatory mechanisms operating mainly at the cellular and subcellular levels of organization [26]. For example, carps progressively cooled from $30^{\circ} \mathrm{C}$ to 23,17 , and $10{ }^{\circ} \mathrm{C}$ showed substantial changes in the fatty acid composition of the endoplasmic reticulum phospholipids, with increasing proportions of unsaturated fatty acids and changes in the activity of other biosynthetic enzymes $[27,28]$.

Animals develop a complicated metabolic system to adapt to changes in nutritional states. In nature, when food is plentiful, animals eat and store the excess energy as lipids. This is a survival strategy for animals when food is not readily available [29]. Lipids are the most important biochemical compounds of fish [30]. Fish store lipids in muscles and liver [31] in contrast to mammals, which 
store lipids in adipose tissue. Most of these lipids are transferred to different parts of the body for various physiological actions [32]. In some fish species, extensive lipid infiltration into the liver is not considered pathological, since the liver works as a major lipid storage organ, especially in autumn $[33,34]$. However, in our study, we found no significant statistical difference in liver alterations between summer and autumn seasons. Kandemir and Polat [31] investigated seasonal and monthly variations in the amount of total lipid and fatty acids in the muscle and liver of reared rainbow trout (Oncorhynchus mykiss). Lipid levels were higher in summer, autumn, and winter than in spring. Furthermore, the amount of total lipid and fatty acid was higher in the liver than in muscle tissue. Active fish store their lipids in muscle tissues, but fish living at the bottom store their lipids in the liver [35], as seen in the Cottus gobio in our study. These considerations seem to corroborate our hypothesis. However, values of $\mathrm{K}$ did not show significant difference between fish from Dimon Lake and Degano Creek, indicating a robustness and good state of nutrition of both populations [36]. In this case, the use of Fulton's condition factor did not allow us to predict the lipid accumulation, as also previously suggested [37].

The second hypothesis rests on the diet of bullhead, and consequently the lipid content of chironomids, which are the only trophic resource available for this species. Bogut and co-workers [38] showed how Chironomus plumosus larvae represent a potential suitable natural component of farm fish, with a crude fat content of $1.3 \%$ and $9.7 \%$ in fresh larvae and dry matter, respectively. Timon-David [39] reported a similar percentage of lipids ( $8.3 \%$ ) for adults of Chironomus spp. and larva. Lipids are high-energy nutrients and typically make up about $7 \%$ to $15 \%$ of a fish diet [40]. Nevertheless, an adult diet of Chironomid larvae may induce liver steatosis in reared male Nothobranchius furzeri [41]. For this reason, we cannot exclude that the presence of only chironomids as feed could be the cause of the steatosis observed in the bullhead samples.

Steatosis can be also induced by environmental contaminants, such as cadmium [42], but we excluded this possibility since $\mathrm{Cd}$ concentrations in bullhead from Dimon Lake were under the limit of quantification $\left(0.02 \mathrm{mg} \mathrm{kg}^{-1}\right)$ as reported by Polazzo [19].

Morphological modifications, such as hepatocyte vacuolization, may also be interpreted as a response to a pathological process caused by infections or parasites [43,44], but we did not find bacteria or parasites in the fish during a survey performed in the same animals as reported by Pastorino and co-workers [7].

Further investigations are needed to explore this phenomenon, for example, by analyzing the composition of the total body fat in chironomids present in the lake or by determining the lipid profile in the livers of bullhead specimens.

All organisms need to adapt to their habitat if they are to survive. Our results suggest that fish may also implement strategies, such as physiological changes (lipid accumulation) or changes in feed preferences, to survive in adverse conditions.

Author Contributions: Conceptualization, P.P. and K.V.; Data curation, P.P. and K.V.; Investigation, P.P., E.P., M.B., D.R.F., V.M., D.M. and K.V.; Methodology, P.P., M.P., M.B., D.R.F., V.M., D.M. and E.B.; Software, K.V.; Writing-original draft, P.P. and K.V.; Writing—review and editing, M.P., E.P., E.B. and K.V.

Funding: This research received no external funding.

Acknowledgments: Authors express their special thanks to Geostudio RC (Marco Rosa Clot and Luca Rosa Clot) and Ente Tutela Patrimonio Ittico Friuli Venezia-Giulia for its support during fish sampling campaigns and the Municipality of Ligosullo (UD) for the hospitality.

Conflicts of Interest: The authors declare no conflict of interest. 


\section{References}

1. Felip, M.; Wille, A.; Sattler, B.; Psenner, R. Microbial Communities in the Ice and Snow Cover of an Alpine Lake: Evidence for General Patterns, And Lake-Cover Relationship. Aquat. Microb. Ecol. 2002, 29, 123-134. [CrossRef]

2. Ventelä, A.M.; Saarikari, V.; Vuorio, K. Vertical and seasonal distributions of micro-organisms, zooplankton and phytoplankton in a eutrophic lake. In Eutrophication in Planktonic Ecosystems: Food Web Dynamics and Elemental Cycling. Developments in Hydrobiology; Tamminen, T., Kuosa, H., Eds.; Springer: Dordrecht, The Netherlands, 1998; Volume 127, pp. 229-240.

3. Rasmussen, J.B.; Robinson, M.D.; Hontela, A.; Heath, D.D. Metabolic traits of westslope cutthroat trout, introduced rainbow trout and their hybrids in an ecotonal hybrid zone along an elevation gradient. Biol. J. Linn. Soc. 2012, 105, 56-72. [CrossRef]

4. Kang, J.; Ma, X.; He, S. Population genetics analysis of the Nujiang catfish Creteuchiloglanis macropterus through a genome-wide single nucleotide polymorphisms resource generated by RAD-seq. Sci. Rep. 2017, 7, 2813. [CrossRef] [PubMed]

5. Li, Y.; Ren, Z.; Shedlock, A.M.; Wu, J.; Sang, L.; Tersing, T.; Zhong, Y. High altitude adaptation of the schizothoracine fishes (Cyprinidae) revealed by the mitochondrial genome analyses. Gene 2013, 517, 169-178. [CrossRef] [PubMed]

6. Jacobsen, D. Low oxygen pressure as a driving factor for the altitudinal decline in taxon richness of stream macroinvertebrates. Oecologia 2008, 154, 795-807. [CrossRef] [PubMed]

7. Pastorino, P.; Polazzo, F.; Bertoli, M.; Santi, M.; Righetti, M.; Pizzul, E.; Prearo, M. Consequences of fish introduction in fishless Alpine lakes: preliminary notes from a sanitary point of view. Turk. J. Fish. Aquat. Sci. 2019, 1, 1-8.

8. Froese, R. Cube law, condition factor and weight-length relationships: history, meta-analysis and recommendations. J. Appl. Ichthyol. 2006, 22, 241-253. [CrossRef]

9. Biney, C.; Amazu, A.T.; Calamari, D.; Kaba, N.; Mbome, I.L.; Naeve, H.; Ochumba, P.B.O.; Osibonjo, O.; Radegonde, V.; Saad, M.A.H. Review of Heavy Metals in the African Aquatic Environment. Ecotoxicol. Environ. Saf. 1994, 31, 134-159. [CrossRef]

10. Tiberti, R.; Brighenti, S.; Canedoli, C.; Iacobuzio, R.; Rolla, M. The diet of introduced brook trout (Salvelinus fontinalis; Mitchill, 1814) in an alpine area and a literature review on its feeding ecology. J. Limnol. 2016, 75, 488-507. [CrossRef]

11. Caballero, M.J.; Izquierdo, M.S.; Kjorsvik, E.; Fernandez, A.J.; Rosenlund, G. Histological alterations in the liver of sea bream, Sparus aurata L., caused by short- or long-term feeding with vegetable oils. Recovery of normal morphology after feeding fish oil as the sole lipid source. J. Fish Dis. 2004, 27, 531-541. [CrossRef]

12. Luna, L.G. Manual of Histologic Staining Methods of the Armed Forces Institute of Pathology, 3rd ed.; McGraw-Hill: New York, NY, USA, 1968; pp. 1-258.

13. Tiberti, R.; von Hardenberg, A.; Bogliani, G. Ecological impact of introduced fish in high altitude lakes: a case of study from the European Alps. Hydrobiologia 2014, 724, 1-19. [CrossRef]

14. Dawidowicz, P.; Gliwicz, M. Food of brook charr in extreme oligotrophic conditions of an alpine lake. Environ. Biol. Fishes 1983, 8, 55-60. [CrossRef]

15. Mills, C.A.; Mann, R.H.K. The bullhead Cottus gobio, a versatile and successful fish. In Fifty-First Annual Report for the Year Ended 31st March 1983; Freshwater Biological Association (Annual Report), Ed.; Freshwater Biological Association: Ambleside, UK, 1983; pp. 76-88.

16. Forneris, G.; Paradisi, S.; Specchi, M. Pesci D'acqua Dolce; Carlo Lorenzini Editore: Udine, Italy, 1990; pp. 1-21.

17. Ente Tutela Patrimonio Ittico, Regione Friuli Venezia-Giulia; Udine, Italy. Personal communication, 2017.

18. Buckland, A.; Baker, R.; Neil, L.; Sheaves, M. Standardizing fish stomach content analysis: The importance of prey condition. Fish. Res. 2017, 196, 126-140. [CrossRef]

19. Polazzo, F. Alpine Lakes as Indicators of Global Change: Two Examples from Italian Alps. Master's Thesis, University of Trieste, Trieste, Italy, 24 March 2018.

20. Copp, G.H.; Warrington, S. Comparison of diet in bullhead, Cottus gobio and stone loach, Barbatula barbatula in a small English lowland. Folia Zool. 1994, 43, 171-176.

21. Dahl, J. Effects of a benthivorous and a drift-feeding fish on a benthic stream assemblage. Oecologia 1998, 116, 426-432. [CrossRef] 
22. Copp, G.H.; Spathari, S.; Turmel, M. Consistency of diel behaviour and interactions of stream fishes and invertebrates during summer. River Res. Appl. 2005, 21, 75-90. [CrossRef]

23. Gabler, H.M.; Amundsen, P.A. Resource partitioning between Siberian sculpin (Cottus poecilopus Heckel) and Atlantic salmon parr (Salmo salar L.) in a sub-arctic river, northern Norway. Ecol. Freshw. Fish 1999, 8, 201-208. [CrossRef]

24. Vlach, P.; Švátora, M.; Dušek, J. The food niche overlap of five fish species in the Úpoř brook (Central Bohemia). Knowl. Manag. Aquat. Ecosyst. 2013, 411,1-12. [CrossRef]

25. Števove, B.; Babel'ová, M.; Haruštiaková, D.; Kováč, V. When a river is affected by a reservoir: Trophic interactions and flexibility in feeding strategies of alpine bullhead (Cottus poecilopus) and European bullhead (Cottus gobio). Sci. Total Environ. 2019, 651, 1903-1912. [CrossRef]

26. Hochachka, P.W.; Somero, G.N. Biochemical Adaptation; Princeton University Press: Princeton, NJ, USA, 1984; pp. 1-560.

27. Cossins, A.R. Temperature Adaptation of Biological Membranes; Portland Press: London, UK, 1994; pp. 63-75.

28. Trueman, R.J.; Tiku, P.E.; Caddick, M.X.; Cossins, A.R. Thermal thresholds of lipid restructuring and Delta (9)-desaturase expression in the liver of carp (Cyprinus carpio L.). J. Exp. Biol. 2000, 203, 641-650.

29. Marshall, D.M. Starvation physiology: Reviewing the different strategies animals use to survive common challenge. Comp. Biochem. Physiol. Part A Mol. Integr. Physiol. 2010, 156, 1-18.

30. Akpınar, M.A. Cyprinus carpio L. (Osteichthyes: Cyprinidae) karaciğer ve kasındaki total lipid ve total yağ asidinin mevsimsel değişimi. Çukurova Üniversitesi Fen Bilimleri Dergisi 1986, 4, 33-42.

31. Kandemir, S.; Polat, N. Seasonal variation of total lipid and total fatty acid in muscle and liver of Rainbow trout (Oncorhynchus mykiss W, 1792) reared in Derbent Dam Lake. Turk. J. Fish. Aquat. 2007, 5, $27-31$.

32. Yılmaz, Ö. Elazı̆̆ Hazar Gölü'nde yaşayan Capoeta capoeta umbla (Heckel, 1843)'in Total Yağ Asidi Miktarı ve Yă̆ Asitleri Cinslerinin Mevsimlere Göre Değişimi. F.U. Fen Bilimleri Enstitüsü. Biyoloji Anabilim Dalı. Ph.D. Thesis, Firat University, Elazığ, Turkey, 1995.

33. Roberts, R.J. (Ed.) Fish Pathology, 2nd ed.; Bailliere Tindall: London, UK, 1989; pp. 1-466.

34. Spisni, E.; Tugnoli, M.; Ponticelli, A.; Mordenti, T.; Tomasi, V. Hepatic steatosis in artificially fed marine teleosts. J. Fish Dis. 1998, 21, 177-184. [CrossRef] [PubMed]

35. Castell, J.D.; Sinnhuber, R.O.; Lee, D.J.; Wales, J.H. Essential fatty acids in the diet of rainbow trout (Salmo gairdneri): Physiological symptoms of EFA deficiency. J. Nutr. 1972, 102, 87-92. [CrossRef]

36. Murphy, B.R.; Willis, D.W. Fisheries Techniques, 2nd ed.; American Fisheries Society: Bethesda, MD, USA, 1996.

37. Hards, A.R.; Gray, M.A.; Noël, S.C.; Cunjak, R.A. Utility of Condition Indices as Predictors of Lipid Content in Slimy Sculpin (Cottus cognatus). Diversity 2019, 11, 71. [CrossRef]

38. Bogut, I.; Has-Schön, E.; Adámek, Z.; Rajković, V.; Galović, D. Chironomus plumosus larvae-A suitable nutrient for freshwater farmed fish. Agriculture 2007, 13, 1-5.

39. Timon-David, J. Recherches sur les mati6res grasses des insects. Annls. Fac. Sci. Marseille 1930, 4, $28-207$.

40. Craig, S.; Helfrich, L.A. Understanding Fish Nutrition, Feeds and Feeding; Publication 420-256; Virginia Cooperative Extension: Yorktown, VA, USA, 2002; pp. 1-6. Available online: https://pubs.ext.vt.edu/content/ dam/pubs_ext_vt_edu/FST/fst-269/FST-269.pdf (accessed on 4 October 2019).

41. Di Cicco, E.; Terzibasi Tozzini, E.; Rossi, G.; Cellerino, A. The short-lived annual fish Nothobranchius furzeri shows a typical teleost aging process reinforced by high incidence of age-dependent neoplasias. Exp. Geront. 2011, 46, 249-256. [CrossRef]

42. Van Dyk, J.C.; Pieterse, G.M.; van Vuren, J.H.J. Histological changes in the liver of Oreochromis mossambicus (Cichlidae) after exposure to cadmium and zinc. Ecotoxicol. Environ. Saf. 2007, 66, 432-440. [CrossRef]

43. Thomas, P. Molecular and biochemical responses of fish to stressors and their potential use in environmental monitoring. In Biological Indicators in Fish; Adams, S.M., Ed.; American Fisheries Society: Bethesda, MD, USA, 1990; pp. 9-28.

44. Kohler, A.; Deisemann, H.; Lauritzen, B. Histological and cytochemical indices of toxic injury in the liver of dab Limanda limanda. Mar. Ecol. Prog. Ser. 1992, 91, 141-153. [CrossRef]

(C) 2019 by the authors. Licensee MDPI, Basel, Switzerland. This article is an open access article distributed under the terms and conditions of the Creative Commons Attribution (CC BY) license (http://creativecommons.org/licenses/by/4.0/). 